Henssler/Willemsen/Kalb · Arbeitsrecht Kommentar 



\section{Arbeitsrecht Kommentar}

herausgegeben von

Prof. Dr. Martin Henssler

Universität zu Köln

Prof. Dr. Heinz Josef Willemsen Rechtsanwalt, Fachanwalt für Arbeitsrecht, Düsseldorf

Prof. Dr. Heinz-Jürgen Kalb

Vizepräsident des LAG Köln a.D.

9. Auflage

2020

ottoschmidt 
